\title{
Effect of processing including domestic cooking on nutritional quality of legumes
}

\section{By Ann F. Walker and Neena Kochhar, Department of Food Science, University of Reading, London Road, Reading $R G_{1}{ }_{5} A Q$}

Food legumes are divided broadly into two types, those in which energy is stored as lipid material - the leguminous oilseeds such as soya bean and groundnut and those in which energy is stored as starch-the pulses such as peas, beans and lentils. The cluster bean (Cyamopsis tetragonoloba (L.) 'Taub.) is used for the extraction of guar gum and is unusual among the food legumes in that most of the energy is stored as a galactomannan. However, the mature seeds are not normally eaten as food by humans.

Most studies of the effects of processing on grain legumes have been carried out with soya beans; however, in this discussion consideration is primarily given to pulses. Table I shows names of commonly-eaten pulses with the region in which they are eaten. Confusion has arisen in the past over the nomenclature of pulses for several reasons. First, many species previously classified as Phaseolus have now been reclassified as belonging to the genus Vicia. Secondly, common names for two species may be the same, such as the use of the term field bean for varieties of both $P$. vulgaris and $V$. faba (see Table $\mathrm{I}$ ). Finally, a single species may contain within it many morphological types and therefore it is difficult to distinguish the species from the seeds alone. This is particularly true now that unfamiliar varieties are being released from breeding stations. Thus, for example, coloured varieties of cowpea may be identical to seeds of $P$. vulgaris.

Legumes contain a wide range of toxic components (Aykroyd et al. 1981). (The term toxic being defined in the liberal sense according to Liener (1980) as 'an adverse physiological response produced in man or animals by a particular food or substance derived therefrom'). The effects of most of these components are small or negligible in a mixed diet especially when legumes are properly cooked. However, a few (shown in Table 2) deserve mention as their presence in foods does have some public health significance. During the processing of legumes it is important that toxic components be reduced to levels that pose no threat to health. However, improvements in breeding legumes may result in higher levels of toxins, requiring more severe processing conditions for detoxification.

Until recently only those legumes of primary importance in the industrialized countries, such as beans ( $P$. vulgaris), peas, groundnuts and soya beans had received much attention from plant breeders. In the early I970s a number of international agricultural research centres were established for the breeding of tropical and subtropical legumes. At these centres most of the breeding effort is aimed at higher, more stable yield. One aspect which contributes to low yield is the particular susceptibility of legume plants to insect attack in the field. Therefore, 
Table I. Commonly-eaten starchy legumes

\begin{tabular}{|c|c|c|c|}
\hline Common name & Other names & Botanical name & Main region of consumption \\
\hline Adzuki bean & & $\begin{array}{l}\text { Vigna angularis (Willd.) } \\
\text { Ohwit \& Ohashi }\end{array}$ & Asia, especially Japan \\
\hline Bean & $\begin{array}{l}\text { Haricot bean } \\
\text { Kidney bean } \\
\text { Field bean }\end{array}$ & Phaseolus vulgaris $\mathrm{L}$. & World-wide \\
\hline Black gram & Urd & Vigna mungo (L.) Hepper & Asia \\
\hline Broad bean & $\begin{array}{l}\text { Faba bean } \\
\text { Field bean }\end{array}$ & Vicia faba L. & Temperate regions \\
\hline Chickpea & Bengal gram & Cicer arietinum $\mathrm{L}$. & Asia and Middle East \\
\hline Cowpea & $\begin{array}{l}\text { Black-eyed bean (pea) } \\
\text { Southern pea }\end{array}$ & Vigna unguiculata (L.) Walp. & Africa, Asia, South America \\
\hline Lentil & Split pea & Lens culinaris Medik & World-wide \\
\hline L ima bean & Butter bean & Phaseolus lunatus L. & Americas, Africa \\
\hline Mung bean & Green gram & Vigna radiata (L.) Wilcrek & $\begin{array}{l}\text { Asia, world-wide as } \\
\text { beansprouts }\end{array}$ \\
\hline & Field pea & Pisum sativum $\mathrm{L}$. & Temperate regions \\
\hline Pigeon pea & Red gram & Cajanus cajan (L..) Millsp. & Asia, Africa \\
\hline
\end{tabular}

Table 2. Toxic components of legumes of public health significance

\begin{tabular}{|c|c|c|c|}
\hline Toxin & Legumes affected & $\begin{array}{l}\text { Primary associated } \\
\text { disease/symptoms }\end{array}$ & Mode of detoxification \\
\hline Aflatoxin & Groundnuts & Liver cancer in animals & Remove from diet \\
\hline Favism & Faba beans & $\begin{array}{l}\text { Haemolytic anaemia of } \\
\text { susceptible persons, } \\
\text { can be fatal }\end{array}$ & Remove from diet \\
\hline Haemagglutinin & Red kidney bean & $\begin{array}{l}\text { Acute gastroenteritis, } \\
\text { can be fatal }\end{array}$ & Cook sufficiently \\
\hline Lathyrus factor & $\begin{array}{l}\text { Lathyrus pea } \\
\quad(\text { L. sativa } \mathrm{L} .)\end{array}$ & Paralysis of legs & $\begin{array}{l}\text { Dehull, soak overnight, cook } \\
\text { in excess water }\end{array}$ \\
\hline Linamarin & $\begin{array}{l}\text { Black varieties of } \\
\text { lima bean }\end{array}$ & Annoxia, can be fatal & $\begin{array}{l}\text { Crush seeds and soak in } \\
\text { water }\end{array}$ \\
\hline
\end{tabular}

breeding for increased insect resistance forms a large part of legume breeding programmes at all the international institutes. A number of toxic components of legume plants have been shown to confer increased resistance to insect attack or to other pathogens (Liener, 1980). In most cases, however, the nature of the substance (or substances) which increases insect resistance is not known. A high level of toxic constituents in the seed may confer resistance to storage insects, which are a major cause of dry matter loss. Species of Callosobruchus are particularly responsible for this type of damage in legumes. Gatehouse et al. (1979) have established that a high content of trypsin inhibitors in cowpeas is responsible for resistance in storage to $C$. maculata.

Fig. I shows the principal processes used to prepare legumes both domestically and industrially. Germination and fermentation tend to be confined to domestic 
Dehulling

Soaking

\section{Germination}

Fermentation

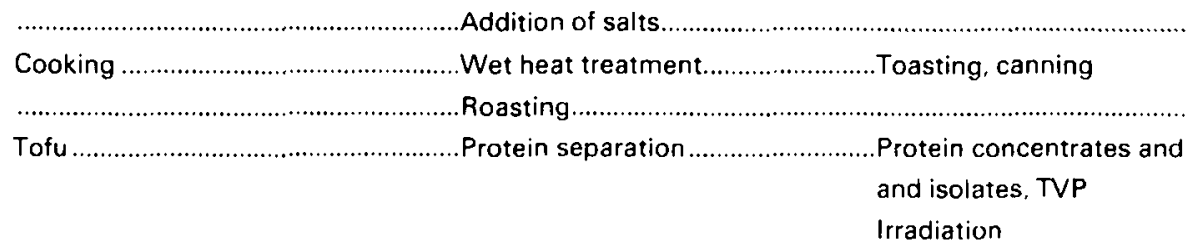

Fig. I. Techniques used in the industrial and domestic processing of legumes.

and irradiation to industrial processing. Irradiation has been used for disinfestation of legumes and is reported to aid the retention of seed quality of pigeon peas during storage (Nene et al. 1975). The main effects of processing on pulses, other than detoxification are to increase palatability, decrease dry matter content, alter the bioavailability of nutrients and reduce the rate of formation of beany flavour.

Arguably one of the main reasons for adding legumes to the largely vegetarian diets of people in less developed parts of the world is to increase the acceptability of monotonous staples and therefore increase energy intake. This is particularly important as the findings of Gershoff et al. (1977) indicate that energy intake is lower than requirements when fortified rice only is eaten.

Data on loss of dry matter is difficult to obtain as many reports on the effects of processing on legumes do not include such information. Table 3 shows loss of dry matter and protein during processing of three cowpea varieties. Considerable loss of weight occurs during dehulling with protein lost in proportion. However, the loss of protein during dehulling will depend on the legume species as Table 5 shows that there is very little protein in the hull of chickpeas.

Table 3. Loss of dry matter and protein during processing of three cowpea varieties

(N. Kochhar and A. F. Walker, unpublished results)

$\begin{array}{lcc}\text { Treatment of whole peas } & \overbrace{\text { Dry }}^{\text {weight }} \begin{array}{c}\text { Protein } \\ (\mathrm{N} \times 6.5)\end{array} \\ \text { Dehulling } & 12.4 & 10.8 \\ \text { Soaking } & 3.1 & 4.7 \\ \text { Soaking and boiling } & 6.4^{\circ} & 4.8^{*}\end{array}$

-Two varieties only. 
Table 4. Comparison of selected nutrients in pulses and other foods $(/ \mathrm{r} 00 \mathrm{~g})$

(Paul \& Southgate, 1978)

$\begin{array}{lcrccc} & \begin{array}{c}\text { Protein } \\ (\mathrm{N} \times 6.25) \\ (\mathrm{g})\end{array} & \begin{array}{c}\mathrm{Ca} \\ (\mathrm{mg})\end{array} & \begin{array}{c}\mathrm{Fe} \\ (\mathrm{mg})\end{array} & \begin{array}{c}\text { Thiamin } \\ (\mathrm{mg})\end{array} & \begin{array}{c}\text { Ribo- } \\ \text { flavin } \\ (\mathrm{mg})\end{array} \\ \text { Beans, haricot, raw } & 21.4 & 180 & 6.7 & 0.45 & 0.13 \\ \text { Peas, dried, raw } & 21.6 & 61 & 4.7 & 0.60 & 0.30 \\ \text { Beef, lean, average, raw } & 20.3 & 7 & 2.1 & 0.07 & 0.24 \\ \text { Fish, cod, raw, fresh } & 17.4 & 16 & 0.3 & 0.08 & 0.07 \\ \text { Rice, polished, raw } & 6.5 & 4 & 0.5 & 0.08 & 0.03\end{array}$

Table 5. Protein, methionine and lysine contents of six uncooked cowpea varieties

(All values except tannins index are means of duplicate analyses; N. Kochhar and A. F. Walker, unpublished results)

\begin{tabular}{|c|c|c|c|c|c|c|}
\hline \multirow[b]{3}{*}{ Variety } & \multirow[b]{3}{*}{$\begin{array}{l}\text { Tannins } \\
\text { Index: }\end{array}$} & \multirow[b]{3}{*}{$\begin{array}{c}\text { Protein } \neq \\
(\mathrm{N} \times 6.25)\end{array}$} & & & \multicolumn{2}{|c|}{ Lysine } \\
\hline & & & \multicolumn{2}{|c|}{ Mehionine $(\mathrm{g} / \mathrm{1} 6 \mathrm{~g} \mathrm{~N})$} & & Available \\
\hline & & & $\begin{array}{l}\text { Total } \\
\text { (IEC) }\end{array}$ & $\begin{array}{c}\text { Available } \\
\text { (Microbiol) }\end{array}$ & $\begin{array}{c}\text { Total } \\
\text { (IEC)§ }\end{array}$ & $\begin{array}{c}(\mathrm{g} / \mathrm{l} 6 \mathrm{~g} \\
\text { protein } \mathrm{N})\end{array}$ \\
\hline $\mathrm{TV}_{\mathrm{u}} \mathrm{I} 469$ & I. 8 & 23.9 & $2 \cdot 0$ & $1 \cdot 3$ & $7 \cdot 1$ & $4 \cdot 8$ \\
\hline$T V_{u} 1035$ & 15 & $24 \cdot 8$ & $2 \cdot 0$ & I. 4 & $7 \cdot 7$ & $4 \cdot 5$ \\
\hline $\mathrm{K}_{2} 809$ & I I I & $22 \cdot 8$ & $2 \cdot 3$ & $1 \cdot 5$ & $7 \cdot 6$ & 54 \\
\hline $\mathrm{TV}_{\mathrm{u}} 76$ & 0.8 & $25 \cdot 2$ & I. 8 & I. 5 & $7 \cdot 3$ & 4.7 \\
\hline$T V_{x}{ }^{1836-19 E}$ & 0.5 & $25 \cdot 2$ & I 5 & I. 5 & 75 & $4 \cdot 3$ \\
\hline Prima & 0.3 & 20.7 & $2 \cdot 0$ & $1 \cdot 5$ & $7 \cdot 0$ & 6.1 \\
\hline LSD & $\ldots$ & 12 & 0.5 & 0.1 & 0.5 & 0.7 \\
\hline
\end{tabular}

DBL, dye-binding lysine (Walker, I 979);

IEC, ion-exchange chromatography of unoxidized acid hydrolysates.

L.SD, least significant difference $(P<0.05)$.

Microbiol, using Streptococcus zymogenes (Ford \& Hewitt, 1979).

-International Institute of Tropical Agriculture, Nigeria, cat. no., except for Prima.

$\therefore$ Determined by acid-methanol extraction (Ford \& Hewitt, 1979).

$\$$ Trichloroacetic-acid precipitated.

$\$ g$ Lysine residue / Ioog amino-acid residues recovered.

The nutrients of main consideration in legumes are protein, calcium, iron, thiamin and riboflavin in which they are comparatively rich. Table 4 shows these nutrients for two pulses as well as for beef, fish and rice. These latter food commodities were chosen for comparison as legumes often displace beef and fish in diets and legumes are commonly eaten with rice.

Much of the research work reported on pulses is concerned with the effects of processing on the protein quality of legumes. 'This is increased by heat treatment, partly due to the loss of toxic effects and partly due to denaturation of legume protein which in its native state is somewhat resistant to digestion (Liener, 1976). 
Further discussion of aspects of protein quality and loss of activity of thiamin and riboflavin is given later.

The limited amount of information in the literature indicates that $\mathrm{Ca}$ and $\mathrm{Fe}$ bioavailability is high, despite the large amount of phytate present. Thus Weingartner et al. (1979) found no effect on $\mathrm{Ca}$ and zinc bioavailability by adding soya-bean hull to soya-bean flour in rat diets and Rotruck \& Luhrsen (1979) found that the bioavailability of $\mathrm{Fe}$ was higher in soya beans than beef. The apparent lack of effect of phytate (the main function of which in the seed is to contain phosphorus which is slowly released for the nutrition of the plant during germination) may be because it is not present in the hull of legumes, in contrast to cereals.

Beany flavour is due to the action of the enzyme lipoxygenase on free fatty acids present in the seed. This leads to the formation of ketones giving undesirable flavours. Storage of the seeds with a moisture content of less than $10 \%$ will slow down this process and heat treatment greater than $80^{\circ}$ will denature the enzyme. Industrially, soya beans are steam treated (toasted) prior to dehulling and grinding to form whole soya-bean flour to reduce the formation of beany flavour.

Although a great deal of information exists in the literature on the effects of processing on various components of grain legumes, there are problems in the interpretation of this data. Varieties of the same legume species differ in their content and availability of components, as seen for protein, lysine and methionine in six varieties of cowpeas with a range of tannin content of the seedcoat in Table 5. Reasons for the large differences in total and available lysine of cowpeas in Table 5 are not known at this stage. Total lysine values are similar to those given for cowpeas by Otoul (1973).

Species may vary not only in composition of nutrients but in type and amount of toxins. Thus results obtained with one species of pulse may not necessarily be applicable to another. Even the length of storage time will also affect certain characteristics of the seeds such as the cooking time (see section on heat treatment). Additionally, methods of sample preparation and analysis may vary considerably from one literature source to another. Bearing these points in mind, certain processes are discussed further for their effect on nutritional quality.

\section{Dehulling}

Dehulling leads to a considerable loss in dry matter (Tables 3 and 6) but has the advantage that with the seedcoat removed, pulses cook more quickly (Kon et al. I 973). The dehulled seed is known as dhal in India. On a domestic level, especially in the less-developed countries, dehulling is normally carried out manually using a pestle and mortar, although in industry large-scale machinery is used. Table 6 shows that from a nutritional point of view for chickpea, the main nutrient lost in this process is $\mathrm{Ca}$. As tannins are mainly confined to the hull, they are also removed during dehulling: Elias et al. (1979) found that the presence of tannins lowered protein quality of beans ( $P$. vulgaris) by reducing digestibility. However, results in 
Table 6. The distribution of some components in the seed parts of chickpeas $(/ \mathrm{I} 00 \mathrm{~g})$

(Lal et al. $\mathrm{I}^{6} 6_{3}$ )

$\begin{array}{lcccc} & \begin{array}{c}\text { Protein } \\ (\mathrm{N} \times 6.25) \\ (\mathrm{g})\end{array} & \begin{array}{c}\text { Crude } \\ \text { fibre } \\ (\mathrm{g})\end{array} & \begin{array}{c}\text { Calcium } \\ (\mathrm{mg})\end{array} & \begin{array}{c}\text { Iron } \\ (\mathrm{mg})\end{array} \\ \text { Seedcoat } & 2 \cdot 9 & 48 \cdot 3 & 1000 & 7 \cdot 3 \\ \text { Cotyledon } & 25 \cdot 0 & 1 \cdot 0 & 70 & 5 \cdot 1 \\ \text { Whole seed } & 21 \cdot \mathrm{I} & 8.9 & 200 & 5 \cdot 6\end{array}$

Reprinted from Experientia 19, I54. ç: 1963 Birkhauser Verlag.

Table 5 indicate that for cowpeas, tannins have little effect on the availability of methionine and lysine.

\section{Soaking}

Soaking is commonly used before cooking as it reduces the cooking time (Molina et al. 1976). During this process there is a loss of solids as shown in Table 3 (mainly low-molecular-weight substances) although Gatfield (I980) showed that trypsin inhibitors have been reported to leach out during soaking of certain species of pulses.

\section{Germination}

The main effect of germination besides the loss of dry matter reported by Kon (1979) is to increase the content of vitamin C. Hsu et al. (1980) showed that for three pulses, the vitamin C content was between $600-800 \mathrm{mg} / \mathrm{kg}$ dry weight of seed after $4 \mathrm{~d}$ of germination, while the ungerminated seed contained negligible quantities. This makes legumes an important source of vitamin $\mathrm{C}$ in some communities during winter months when fresh vegetables are in short supply. Additionally, as would be expected, the phytic acid content of seed is reduced during germination (Tabekhia \& Luh, I980).

Germination increases the protein quality of cereals. However, it has not been shown to have this effect on legumes, indeed Khan \& Ghafoor (1978) showed that cooked, germinated black gram had lower true digestibility for rats than cooked, soaked black gram. However, the problem of the determination of true digestibility of legume protein has been highlighted for $P$. vulgaris by Bender et al. (1979), who found that the true potein digestibility decreased rapidly with increasing concentration of beans in the diets of rats and was much higher in rats of $23 \mathrm{~d}$ old than those of $63 \mathrm{~d}$.

\section{Heat treatment}

Hellendoorn (1979) has shown that brown beans (P. vulgaris) which were stored for different periods of time had varying nutritional value after cooking. Freshly harvested beans rapidly imbibed water on soaking for $\mathrm{I} 6 \mathrm{~h}$, while of those at 
I-year-old, $25 \%$ did not imbibe water during the same soak period. On cooking the seeds for an equal period of time $\left(60 \mathrm{~min}\right.$ at $\left.12 \mathrm{I}^{\circ}\right)$, the digestibility of the starch (determined by in vitro pancreatic amylase digestion) was $93.2 \%$ for the fresh seeds, while only $83.5 \%$ for the I-year-old seeds.

The cooking time of pulses varies with species and variety as well as the length of time in storage. One added difficulty of the interpretation of research in this area is that the methods of determination of cooking time vary considerably. They include subjective methods (cooking until the beans are soft), pressing the cooked beans between two glass slides until no hard material is left (Narasimha \& Desikachar, 1978), instrumental methods based on the use of specialized equipment to measure the pressure needed for a probe to penetrate the seed (Molina et al. 1976) and the level of dispersed solids in the cooking water (Narasimha \& Desikachar, 1978). Müller ( $\mathrm{I}_{967}$ ) found that increased cooking time was associated with increased contents of $\mathrm{Ca}$, magnesium and pectin in the seed. From a practical point of view, Bressani \& Elias (1979) showed that, to prevent the increase in cooking time due to storage time, beans $(P$. vulgaris) should be stored with low moisture content $(<10 \%)$. Another difficulty in this work is that not all seeds of a batch will show the same characteristics: some show hard shell, which is an inability to imbibe water caused by a blockage of the micropyle (Stein, 1976).

The addition of salts to the soaking or cooking water of pulses is often used to reduce the cooking time. Sodium bicarbonate is the most commonly used, although in some parts of the world the ashes from the cooking fuel are used. The disadvantage of alkali treatment is that there is a considerable loss of thiamin. Edijala ( 1980 ) gives values of $51 \%$ thiamin loss for cowpeas cooked in tap water and $80 \%$ loss for those cooked in $0.1 \%$ sodium bicarbonate. However, Evans \& Bauer ( 1978 ) have shown that the protein quality of beans (P. vulgaris) (as measured by rat bioassay) did not alter after sodium bicarbonate treatment. Rockland et al. (1979) have developed a method for the preparation of quickcooking beans $(P$. vulgaris) based on soaking the beans with a mixture of four salts (sodium chloride, sodium tripolyphosphate, sodium carbonate and sodium bicarbonate), rinsing and drying. After this treatment, beans cook in a very short time (6-18 min compared to $40-210 \mathrm{~min}$ for a wide range of legume species). One disadvantage of this method is that energy is needed for drying, which would increase the cost of the end product. Shortening of cooking time is important from a point of view of convenience and the saving of valuable cooking fuel. The latter point is particularly pertinent to developing countries where fucl supplies are scarce.

The main effect of heat treatment of pulses on the nutritional value is to increase the protein quality. Although, as heating proceeds, protein quality increases to a maximum (Table 7), with continued heating it is reduced. The reasons for these changes are that early in the cooking process there is a loss of toxic activity, particularly of the proteinaceous toxins, trypsin inhibitors and haemagglutinins. However, for a variety of pulses, the increase in digestibility on cooking has not been clearly related to detoxification of any one specific toxin, such as the level of 
Table 7. Effect of boiling on nutritive value of whole soaked beans (P. vulgaris)

(Antunes \& Sgarbieri, r 980 )

Time of
boiling
at $97^{\circ}$
(min)
None
$2 \cdot 5$
5
10
15
30

$\begin{array}{cccc}\begin{array}{c}\text { Apparent } \\ \text { in vivo } \\ \text { digestibility } \\ (\%)\end{array} & \begin{array}{c}\text { Trypsin } \\ \text { inhibitor } \\ \text { activity } \\ (\%)\end{array} & \begin{array}{c}\text { Haemagglu- } \\ \text { tinin } \\ \text { activity }\end{array} \\ \text { PER } & \vdots & 100 & 2000 \\ ! & 62 & 34 & 27 \\ 0.9 & 63 & 22 & 13 \\ 1 \cdot 0 & 64 & 13 & 2 \\ 1 \cdot 2 & 63 & 10 & 0.4 \\ 1 \cdot 0 & 62 & 4.5 & 0 \\ 0.07 & 62 & \end{array}$

-Reciprocal of minimum protein concentration capable of haemagglutination.

Death of the rats in $4-8 \mathrm{~d}$.

Reprinted from fournal of Agricultural and Food Chemistry 28, 935. 'C I980 American Chemical Society.

trypsin inhibitors (Table 8). A probable reason is that globulins, which make up the larger portion of legume seed protein, are resistant to denaturation and in the native state are not readily broken down by digestive enzymes. Also, as pulses contain a wide range of toxins, other toxic compounds may be involved in causing low digestibility.

The loss of protein quality of pulses on continued heating is likely to be related to increasing Maillard browning causing lysine to be rendered unavailable. Results in Table 7 suggest that there is no difference in the digestibility of beans ( $P$. vulgaris) prepared by heating for different times. Although there is an increase in digestibility of heated legumes when compared with raw ones (Table 8). The effects of prolonged heating on lysine availability in cowpeas is shown in Table 9. This Table also shows that the availability of methionine is not affected. The autoclaving treatment shown in Table 9 was severe, but results in the same Table show that for soaked/boiled cowpeas $(25-35 \mathrm{~min})$, there was no change in the availability of lysine with respect to the raw material. For soaked/pressure cooked cowpeas ( $\left.12 \mathrm{I}^{\circ}, 15 \mathrm{~min}\right)$, there was a statistically significant lowering $(P<0.05)$ of the availability of lysine with respect to the raw control, but for practical purposes this loss was not great. Thus it would be expected that legumes cooked for the minimum time to make them soft enough to be acceptable would have maximum protein quality. However, in some parts of the world, cooking beans proceeds over many hours, often for reasons of tradition or convenience. Under these conditions, loss of protein quality may be of practical significance. Many legumes, even when cooked, have low digestibility (Table 8), but the work of Rockland \& Radke (1981) would suggest that when legumes are cooked in the presence of other protein, particularly animal products, there is a marked increase in their digestibility.

As to the other constituents of legumes, studies of the effect of heating are few. However, Augustin et al. (198I) report the retention of a wide range of vitamins and minerals in cooked beans $(P$. vulgaris). Retention of most mineral components was high, while that of the $B$ vitamins ranged from $70-76 \%$. 
Table 8. Effect of cooking on the digestibility and PER of selected legumes showing trypsin inhibitor activity

(Liener, r 976)

\begin{tabular}{|c|c|c|c|c|c|}
\hline \multirow[b]{2}{*}{ Legume } & \multirow{2}{*}{$\begin{array}{c}\text { Trypsin } \\
\text { inhibitor } \\
\text { activity } \\
\times 10^{-4} \\
\text { units } / g\end{array}$} & \multicolumn{2}{|c|}{ Digestibility $(\%)$} & \multicolumn{2}{|c|}{ PER } \\
\hline & & Raw & Heated & Raw & Heated \\
\hline Kidney beans & $4 \cdot 3$ & $5^{6}$ & 80 & - & 0.8 \\
\hline Hyacinth beans & $4 \cdot 4$ & 57 & 82 & - & I. 3 \\
\hline Soya beans & $4 \cdot 2$ & 70 & 85 & I. 3 & $2 \cdot 4$ \\
\hline Lima beans & $4 \cdot 0$ & 34 & $5 I$ & - & 0.7 \\
\hline Pigeon peas & $2 \cdot 8$ & 59 & 60 & 0.7 & 1.6 \\
\hline Cowpeas & I. 9 & 79 & 83 & $1 \cdot 4$ & $2 \cdot 2$ \\
\hline Lentils & I. 8 & 88 & 93 & 0.4 & $1 \cdot 2$ \\
\hline
\end{tabular}

Reprinted from fournal of Food Science 41, 1076.

Table 9. Effect of heat treatment on the availability of methionine and lysine in cowpeas

(Mean of duplicate analyses for three varieties; N. Kochhar and A. F. Walker, unpublished results)

\begin{tabular}{|c|c|c|}
\hline Treatment & $\begin{array}{c}\text { Available methionine } \\
(\mathrm{g} / \mathrm{1} 6 \mathrm{~g} \mathrm{~N}) \\
\text { (Microbiol) }\end{array}$ & $\begin{array}{c}\text { Available lysine } \\
\text { (g/16 g protein } N) \\
\text { (DBI) }\end{array}$ \\
\hline None & I 4 & $5 \cdot 3^{a}$ \\
\hline Autoclaving $\left(12 \mathrm{I}^{\circ}\right): 15 \mathrm{~min}$ & I. 5 & $5 \cdot 2^{a}$ \\
\hline $\begin{array}{cc}\text { (dry seeds) } & 30 \mathrm{~min} \\
\mathrm{I} \mathrm{h}\end{array}$ & $\begin{array}{l}\text { I. } 5 \\
\text { I. } 6\end{array}$ & $\begin{array}{l}5 \cdot 4^{\mathrm{a}} \\
4 \cdot 6^{\mathrm{b}}\end{array}$ \\
\hline $2 \mathrm{~h}$ & $1 \cdot 5$ & $4 \cdot I^{c}$ \\
\hline Soaking and boiling $4^{\mathrm{h}}$ & 1. 4 & $2 \cdot 8^{d}$ \\
\hline $\begin{array}{l}(25-35 \mathrm{~min}) \\
\text { Soaking and pressure } \\
\text { cooking }\left(121^{\circ}-15 \mathrm{~min}\right)\end{array}$ & $1 \cdot 5^{\circ}$ & $\begin{array}{l}5 \cdot \mathrm{I}^{\mathrm{a}} \\
\cdot 8^{\mathrm{b}}\end{array}$ \\
\hline
\end{tabular}

\section{Protein separation}

Most protein separation has been carried out using wet concentration techniques with soya beans. Domestically, soya-bean curd or tofu is produced from soya-bean milk by precipitation of the protein with calcium salts. The resulting curd has protein quality equal to that of cooked soya beans (Liener, 1977).

Industrially, proteins from soya beans are divided into concentrates $>70 \%$ protein), obtained by leaching defatted soya-bean meal, or isolates ( $>90 \%$ protein), which are produced from defatted soya-bean meal by successive solubilization and precipitation of the protein in alkali and acid. These products are now being used 
extensively as meat replacers in food manufacture. There is very little difference in the protein quality of soya-bean isolates and cooked soya beans, although the isolates have slightly lower levels of sulphur-containing amino acids (Liener, 1977). For further discussion of the use of soya beans and their products in human nutrition see Wilcke et al. (1979).

From the point of view of the food technologist, changes of nutritional value are not as important as loss of functional properties of the protein during processing, caused by denaturation. Retention of functional properties means that the protein is able, for example, to absorb water or fat, to be solubilized under certain conditions, and may have foaming and emulsification properties. In foods it is important that these properties be maintained to provide 'chewy' or other textural properties.

Soya-bean meal is normally toasted (steamed at atmospheric pressure) before processing and the extent of denaturation of the protein is determined by the NSI ( $\mathrm{N}$ solubility index). This is the percentage of total nitrogenous constituents (primarily protein) that is dispersible in water under specified conditions. The main objective in heating soya-bean meal in this manner is to reduce trypsin inhibitor activity to a minimum as this increases protein quality. The absence of trypsin inhibitors is monitored by the destruction of urease activity as this is easier to determine. For soya beans, trypsin inhibitors are inactivated at the same rate as urease (Albrecht et al. 1966), but this may not necessarily be so for other legumes. There has been relatively little work on protein concentrates from pulses reported in the literature, although some work is now underway on the preparation of a protein concentrate by a dry milling technique called air classification (Vose $e t$ al. 1976). This method has the advantage that there is little or no effect on functional properties of the protein, although processing conditions suitable for detoxification will have to be determined before these legume fractions can be used in food manufacture.

\section{Conclusion}

Legumes or pulses play a key role in the acceptability of monotonous diets in many parts of the world, therefore it is important that consumer preferences and acceptability are considered in legume breeding programmes. With judicious processing the loss of nutritional value of grain legumes can be minimized and protein quality maximized. However, there is a need to investigate factors which will reduce cooking time for a wide range of grain legume species. Studies are also needed on the rates of detoxification during processing of legumes other than soya beans, particularly for the newly-released varieties from the international agricultural research institutes which have high insect resistance. For the food technologist, interested in the manufacture of food products, the type of experiments described earlier, leading to the study of the destruction of nutrients (in particular protein quality), are meaningless, as the long heat treatments used result in loss of functional properties of the protein. If protein concentrates and isolates are to be produced from other legumes, information on the effects of 
Vol. 4 I

processing on functional properties are needed, together with rates of detoxification and nutritional quality changes.

The authors are grateful to Dr J. E. Ford for guidance with the microbiological assay for available methionine.

\section{REFERENCES}

Albrecht, W. J., Mustakas, G. C. \& McGhee, J. E. (1966). Cereal Chem. 43, 400.

Antunes, P. L. \& Sgarbieri, V. C. (1980). F. agric. Fd Chem. 28, 935.

Augustin, J., Beck, C. B., Kalbfleish, G. \& Kagel, L. C. (1981). Fd Technol. 35 (3), 75 .

Aykroyd, W. R., Doughty, J. \& Walker, A. F. (1981). Legumes in Human Nutrition, 2nd edition, FAO Nutritional Studies No. I9. Rome: FAO.

Bender, A. E., Mohammadiha, H. \& Almas, K. (1979). Qual. Plant. 29, 219.

Bressani, R. \& Elias, L. G. (1979). Fd Nutr. Bull. (UN) ז, 23.

Edijala, J. K. ( I 980). Y. Fd Technol. I 5, 445 .

Elias, L. G., Fernandez, D. G. de \& Bressani, R. (1979). F. Fd Sci. 44, 524.

Evans, R. J. \& Bauer, D. H. (1978). F. agric. Fd Chem. 26, 779.

Ford, J. E. \& Hewitt, D. (1979). Br. F. Nutr. 4I, 34I.

Gatehouse, A. M. R., Gatehouse, J. A., Dobie, P., Kilminster, A. M. \& Boulter, D. (1979). J. Sci. Fd Agric. 30, 948 .

Gatfield, I. L. (1980). Lebensm.-Wiss. u.-Technol. $13,4^{6}$.

Gershoff, S. N., McGandy, R. B, Suttapreyasri, D., Promkutkae, N. A., Pisolyabutra, L., Tantiwongse, P. \& Viravaidhoya, V. (1977). Am. F. clin. Nutr. 30, I 185

Hellendoorn, E. W. (1979). Qual. Plant. 29, 227.

Hsu, D., Leung, H. K., Finney, P. L. \& Morad, M. M. (1980). F. Fd Sci. 45,87.

Khan, M. A. \& Ghafoor, A. (1978). F. Sci. Fd Agric. 29, 46 I.

Kon, S. (1979). F. Fd Sci. 44, 1329.

Kon, S., Dhanneson, A. V. \& Booth, A. N. (1973). F. Fd Sci. 38, 496.

Lal, B. M., Prakash, V. \& Verma, S. C. (1963). Experientia 19, I 54.

Liener, I. E. (1976). F. Fd Sci. 41, 1076.

Liener, 1. E. (1977). Э. Am. Oil Chem. Soc. 54, 454A.

Liener, I. E. (editor) (1980). Toxic Constituents of Plant Foodstuffs, and ed. New York: Academic Press.

Molina, M. R., Baten, M. A., Gomez-Brenes, R. A., King, K. W. \& Bressani, R. (1976). F. Fd Sci. 4I, 66I.

Müller, F. M. (1967). F. Sci. Fd Agric. 18, 292.

Narasimha, H. V. \& Desikachar, H. S. R. (1978). F. Fd Sci. Technol. 15, 47.

Nene, S. P., Vakil, U. K. \& Sreenivasan, A. (1975). F. Fd Sci. 40, 815.

Otoul, E. (1973). Bull. des Recherches Agronomique de Gembloux 8, 124.

Paul, A. A. \& Southgate, D. A. T. (1978). McCance and Widdowson's The Composition of Foods,

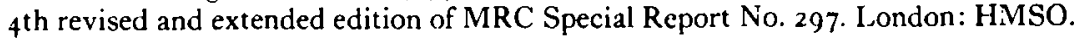

Rockland, I. B. \& Radke, T. M. ( I981). Fd Technol. 35, (3), 79.

Rockland, L. B., Zaragosa, E. M. \& Oracca-Tetteh, R. (1979). F. Fd Sci. 44, 1004.

Rotruck, J. T. \& Luhrsen, K. R. (1979). J. Agric. Fd Chem. 27, 27.

Stein, M. (1976). Qual. Plant. 26, 227.

Tabckhia, M. M. \& Luh, B. S. (1980). F. Fd Sci. 45, 406.

Vose, J. R., Basterrechea, M. J., Gorin, P. A. J., Finlayson, A. J. \& Youngs, C. G. (1976). Cereal Chem. 53, 928 .

Walker, A. F. (1979). Br. F. Nutr. 42, 445

Weingartner, K. E., Erdman, J. W. Jr., Parker, H. M. \& Forbes, R. M. (1979). Nutr. Rep. Int. 19, 223.

Wilcke, H. L., Hopkins, D. T. \& Waggle, D. H. (eds) (1979). Soy protein and human nutrition. New York: Academic Press. 